\title{
Corrosion Behavior of API 5L X52 Steel under High Concentrations of $\mathrm{H}_{2} \mathrm{~S} / \mathrm{CO}_{2}$ Gases*
}

\author{
Mónica Jazmín Hernández Gayossoํ, Gerardo Zavala Olivares", Saúl Bautista Fragoso1, \\ Gabriel Ernesto Blanco del Valle1, Daniel Mauricio Godínez Oidor², Víctor Ángel Rodríguez Gómez² \\ ${ }^{1}$ Instituto Mexicano del Petróleo, Eje Central Lázaro Cárdenas Norte 152, San Bartolo Atepehuacan, Gustavo A. Madero, \\ Ciudad de México, México \\ ${ }^{2}$ Pemex Exploración Producción, Carretera Carmen-Puerto Real Km 4.5, Colonia Renovación, Edificio Kaxan, Campeche, México, \\ Email: "gzavala@imp.mx
}

How to cite this paper: Gayosso, M.J.H., Olivares, G.Z., Fragoso, S.B., del Valle, G.E.B., Oidor, D.M.G. and Gómez, V.Á.R. (2016) Corrosion Behavior of API 5L X52 Steel under High Concentrations of $\mathrm{H}_{2} \mathrm{~S} /$ $\mathrm{CO}_{2}$ Gases. Materials Sciences and Applications, 7, 623-643.

http://dx.doi.org/10.4236/msa.2016.710051

Received: June 14, 2016

Accepted: October 17, 2016

Published: October 20, 2016

Copyright $\odot 2016$ by authors and Scientific Research Publishing Inc. This work is licensed under the Creative Commons Attribution International License (CC BY 4.0).

http://creativecommons.org/licenses/by/4.0/

\section{(c) (i) Open Access}

\begin{abstract}
In the present work, the susceptibility of API 5L X52 steel to corrosion processes was evaluated in the presence of high contents of hydrogen sulfide and carbon dioxide. Gravimetric tests and surface analyses were carried out to establish both the corrosion rate and damage type exhibited by the metal. The obtained results indicate that the hydrogen sulfide is the most active gas in the corrosion processes that took place, quite above carbon dioxide. The main observed corrosion products were iron sulfides and the typical damage associated with hydrogen sulfide presence was Sulfide Stress Cracking (SSC). The surface damage evidences the presence of cracks with considerable magnitude and metal loss as consequences of the corrosion processes. Likewise, the presence of oxygen in the system modifies the displayed corrosion type, where corrosion products such as iron oxides and reduction in the number and extent of cracks are observed. On the other hand, the addition of a film-forming corrosion inhibitor based on modified imidazolines eliminates completely the development of cracks, although under certain test conditions, it can favor localized pitting corrosion.
\end{abstract}

\section{Keywords}

$\mathrm{H}_{2} \mathrm{~S}$ Corrosion, Cracking, Corrosion İnhibition

\section{Introduction}

The quality of crude oil transported through pipelines is subjected to constant changes according to the exploitation time of reservoirs. In addition, this quality is also modifi-

${ }^{*}$ Corrosion behavior of API 5L X52 steel under high concentration of $\mathrm{H}_{2} \mathrm{~S} / \mathrm{CO}_{2}$. 
ed by the incorporation of currents coming from other hydrocarbon production fields.

From the corrosion point of view and more specifically for the case of the Gulf of Mexico region, currently, the transported hydrocarbons present, on average, maximal hydrogen sulfide and carbon dioxide contents in the order of $4 \%$ in the gas, in addition to around $20 \%$ of formation free water in oil. These fluids are handled under acceptable security conditions throughout the pipeline network already present in the region, which is made mainly of API 5L X52 steel.

In addition, maintenance and inner-corrosion-control prevention systems have been implemented, which consider the dosage of film-forming corrosion inhibitors. Currently, the used product formulation is based on modified imidazolines, being this kind of compounds the most common in the oil industry, due to their high protection efficiency in acid environments and good cost/benefit ratio [1] [2] [3].

On the other hand, hydrocarbons that are being produced in new fields feature high hydrogen sulfide, carbon dioxide and water contents, which are above those currently handled by far. These fluids have to be transported also through the pipeline network already existent in the region.

Due to this situation, the estimation of hydrogen sulfide and carbon dioxide concentration above $20 \%$ and the increasing free water content, there is uncertainty as to the effect that the aforementioned conditions will exert on the corrosion control of API 5L X52 steel. The performance of this material is still being studied under the new operation conditions. Although different studies using high hydrogen sulfide/carbon dioxide concentrations have been carried out, they have been aimed mainly to establish the formation mechanisms of corrosion products on the steel surface [4]-[12], without taking into account the corrosion type and its effect on the metal integrity. The previously mentioned becomes relevant when oil industry facilities operate under high pressure and temperature conditions are considered.

According to the facts mentioned above, the present research work was performed as a first approach to establish both the magnitude of the variables related to the conditions to which the pipeline steel will be exposed and the performance of the corrosion inhibitor currently dosed in the oil pipelines.

\section{Experimental}

The experimental design considered 6 corrosion evaluation tests, which were carried out using synthetic brine [13] modified at $10 \%$ sodium chloride in a pressured vessel at $70 \mathrm{~kg} \cdot \mathrm{cm}^{-2}$ and flow rate of 600 revolutions per minute (RPM). All the tests were performed for 24 hours.

At first, the hydrogen sulfide/carbon dioxide effect at saturation level was established displacing air with high purity nitrogen (99.99\%), which provided an environment with a minimal oxygen content (below $0.005 \mathrm{mg} \cdot \mathrm{L}^{-1}$ ) to evaluate the corrosion rate at two different temperatures with and without (blanks) corrosion inhibitors as shown in Table 1. Afterwards, tests without air displacement were performed, which resulted in an oxygen content around $0.1 \pm 0.01 \mathrm{mg} \cdot \mathrm{L}^{-1}$. The tests were carried out at $115^{\circ} \mathrm{C}$ (Table 2). 
Table 1. Test conditions for establishing the corrosion rate in hydrogen sulfide/carbon dioxide saturated solutions.

\begin{tabular}{cccc}
\hline Test Number & Test Description & Temperature $\left({ }^{\circ} \mathrm{C}\right)$ & Inhibitor Concentration $\left(\mathrm{mg} \cdot \mathrm{L}^{-1}\right)$ \\
\hline 1 & Blank & 70 & 0 \\
2 & Inhibitor Evaluation & 70 & 50 \\
3 & Blank & 115 & 0 \\
4 & Inhibitor Evaluation & 115 & 50 \\
\hline
\end{tabular}

Table 2. Test conditions for establishing the corrosion rate in hydrogen sulfide/carbon dioxide saturated solutions with oxygen presence.

\begin{tabular}{cccc}
\hline Test Number & Test Description & Temperature $\left({ }^{\circ} \mathrm{C}\right)$ & Inhibitor Concentration $\left(\mathrm{mg} \cdot \mathrm{L}^{-1}\right)$ \\
\hline 5 & Blank & 115 & 0 \\
6 & Inhibitor Evaluation & 115 & 50 \\
\hline
\end{tabular}

Evaluation of the corrosion rate by weight loss. Two rotating cage pieces of equipment [14] [15] connected in a parallel arrangement were used to establish a uniform gas flow (Figure 1) for each test set, one piece of equipment for the reference blank and the other for the corrosion inhibitor.

Preparation and coupons handling. The steel used to carry out the tests had the same specification as the one employed in the construction of pipelines: API 5L X52 steel. Table 3 shows the typical chemical composition of this material.

The corrosion coupons were cut in order to have $75 \times 19 \times 3 \mathrm{~mm}$ dimensions and polished to reach a 1200 abrasive paper finishing. The coupons were conditioned for the tests according to the procedures described in the corresponding standards [16] [17]. Every rotating cage held 8 coupons.

Test conditions. Two liters of synthetic brine [18] (Figure 2) were poured into each piece of equipment and when applicable, air was displaced with nitrogen. Afterwards, hydrogen sulfide and carbon dioxide gases were bubbled simultaneously in order to reach the saturation concentrations, establishing the $\mathrm{pH}$ of each solution [19]. Once the corrosive medium was settled, the equipment conditioning was carried out until reaching the specific operation conditions for each test set, starting it with the corresponding flow and temperature conditions and increasing the internal autoclave pressure with nitrogen.

In the case of tests 2, 4 and 6 (Table 1 and Table 2), a modified-imidazoline-based corrosion inhibitor was used. It is considered that this additive is specially designed to be partitioned in the aqueous phase and aimed to controlling the corrosion caused by the combined action of hydrogen sulfide and carbon dioxide present in oil-gas, oil and gas pipelines.

Coupons analyses and weight loss determination. At the end of the tests, the sediments accumulated on the surface of the coupons were removed to be analyzed. Afterwards, chemical cleansing was carried out: a) cleaning with anhydrous acetone, b) cleaning with inhibited acid, c) neutralization of inhibited acid, d) cleaning with rubber 
Table 3. Chemical composition of API 5L X52 steel.

\begin{tabular}{cc}
\hline Element & Weight \% \\
\hline $\mathrm{C}$ & 0.16 \\
$\mathrm{Si}$ & 0.45 \\
$\mathrm{Mn}$ & 1.65 \\
$\mathrm{~S}$ & 0.01 \\
$\mathrm{P}$ & 0.02 \\
$\mathrm{~V}$ & 0.07 \\
$\mathrm{Nb}$ & 0.05 \\
$\mathrm{Ti}$ & 0.04 \\
$\mathrm{Fe}$ & Balance \\
\hline
\end{tabular}

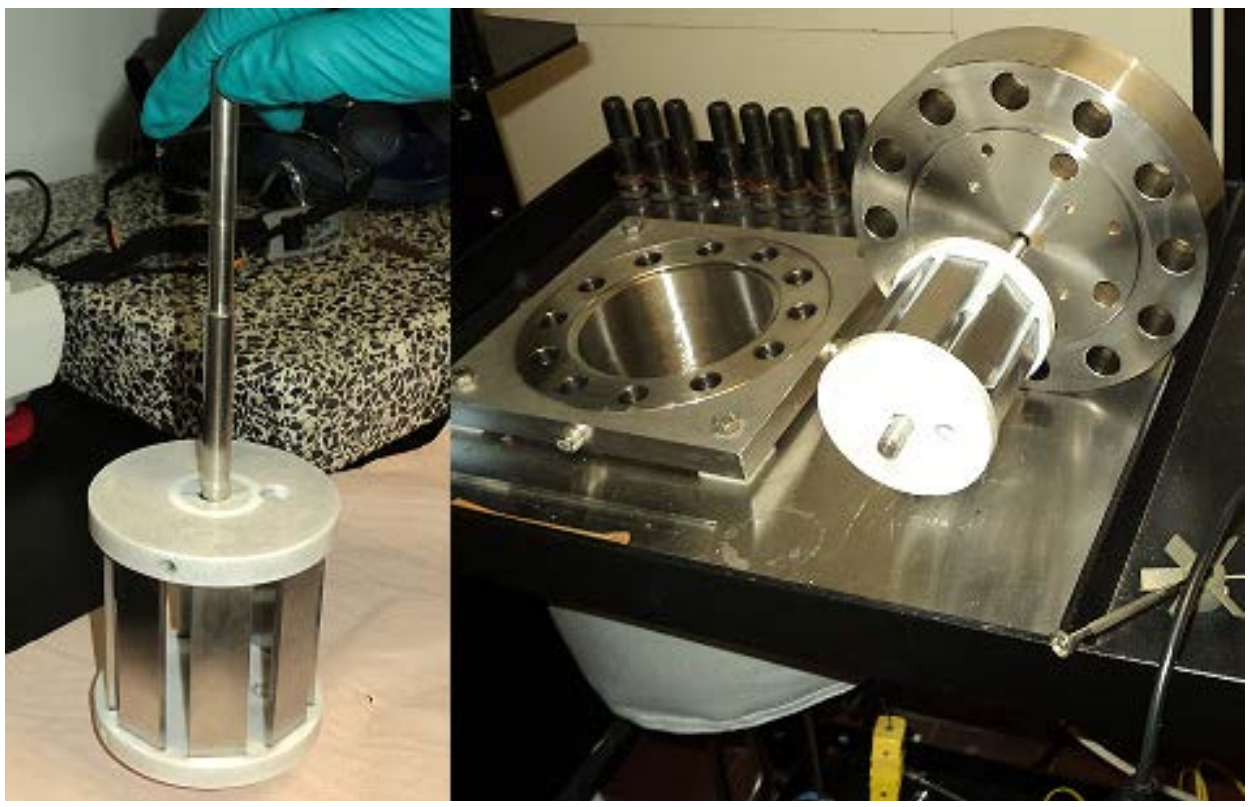

Figure 1. Rotating cage. Carrousel-type accessory for mounting corrosion coupons.

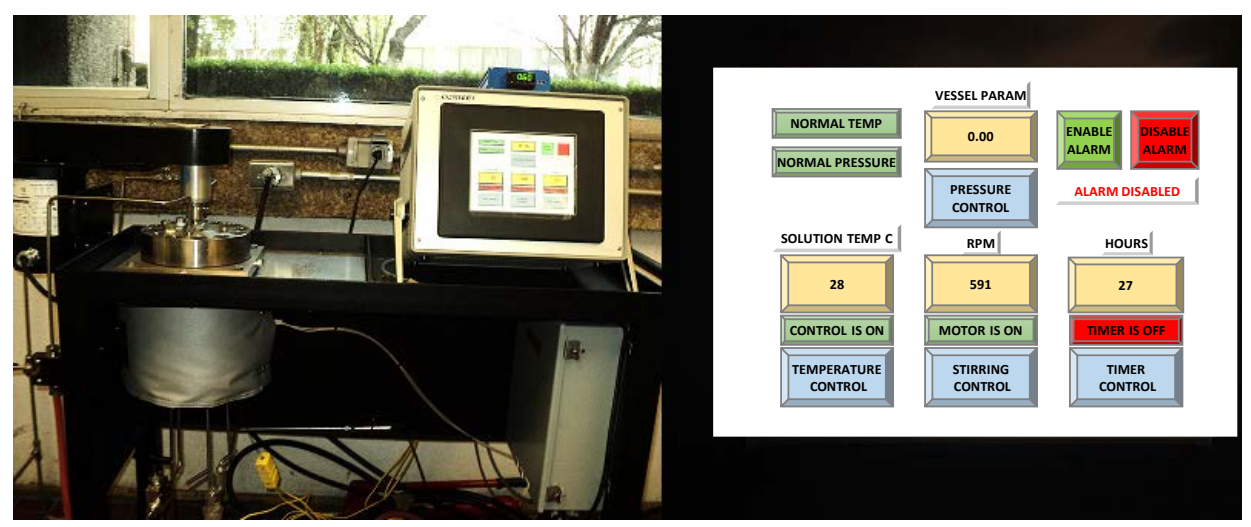

Figure 2. Experimental setup for rotating cage tests. 
cap and e) dehydration with anhydrous acetone. The coupons were preserved in a desiccator until reaching constant weight to calculate the corrosion rate [16]. The average corrosion rate was calculated as follows:

$$
\text { orrosion rate }=\frac{K \times W}{A \times T \times D}
$$

where:

$K=$ Constant $\left(8.76 \times 10^{4}\right.$ for $\mathrm{mm}_{\text {year }}{ }^{-1}$ and $3.45 \times 10^{6}$ for $\left.\mathrm{mpy}\right)$,

$T=$ Time of exposure in hours,

$A=$ Area in $\mathrm{cm}^{2}$,

$W=$ Mass loss in grams,

$D=$ Density in $\mathrm{gcm}^{-3}$ (7.85 for low alloy steels)

Surface analysis. The surface analysis was carried out by scanning electron microscopy, in high vacuum mode and using a secondary electron detector for the image formation without previous sample preparation. A microscope XL30 ESEM (Philips) equipped with a tungsten filament at acceleration voltage of $25 \mathrm{kV}$ was used.

Analysis of corrosion products. Mössbauer Spectroscopy (MS). Transmission Mössbauer spectra were recorded at $27^{\circ} \mathrm{C}$ with a conventional constant acceleration spectrometer (Wissel-Electronik), which was equipped with a krypton proportional detector. The $\gamma$-radiation source was $57 \mathrm{Co}$ of $925 \mathrm{MBq}(25 \mathrm{mCi})$ within a rhodium matrix maintained at room temperature. The chemical isomer shift $(\delta)$ data are given relative to $\alpha$-Fe. The absorption spectra were fitted using the NORMOS software [20].

\section{Results}

\section{Tests 1 and 2.}

The $\mathrm{pH}$ of the solutions used in the tests was 2.83 in both cases. On the other hand, the corrosion rate was considerably lower in the test carried out with corrosion inhibitor presence, Table 4 . The corrosion inhibitor efficiency under the experimental conditions was $94.30 \%$.

Here, the corrosion blanks obtained from Test 1 showed solids adhered to the surface whereas the blanks from Test 2 were found practically clean. This situation was expected, considering the low corrosion rate values exhibited by the steel coupons exposed to the corrosion inhibitor presence.

The corrosion products from Test 1 were analyzed by Mössbauer Spectroscopy (Figure 3), which shows the presence of oxides and iron sulfides, which are commonly observed in the sediments present in pipelines that transport sour hydrocarbons.

Table 4. Corrosion rates at $70^{\circ} \mathrm{C}$, hydrogen sulfide/carbon dioxide saturation, $70 \mathrm{~kg} \cdot \mathrm{cm}^{-2}$ and flow rate of 600 RPM.

\begin{tabular}{cccc}
\hline \multicolumn{2}{c}{ Test 1 blank without inhibitor } & Test $250 \mathrm{mg} \cdot \mathrm{L}^{-1}$ of corrosion inhibitor \\
\hline $\begin{array}{c}\text { Average value of the } 8 \\
\text { used blanks }\end{array}$ & $\begin{array}{c}2.103 \mathrm{~mm} \cdot \mathrm{year}^{-1} \\
(82.85 \mathrm{mpy})\end{array}$ & $\begin{array}{c}\text { Average value of the } 8 \\
\text { used blanks }\end{array}$ & $\begin{array}{c}0.120 \mathrm{~mm} \cdot \mathrm{year}^{-1} \\
(4.72 \mathrm{mpy})\end{array}$ \\
\hline
\end{tabular}




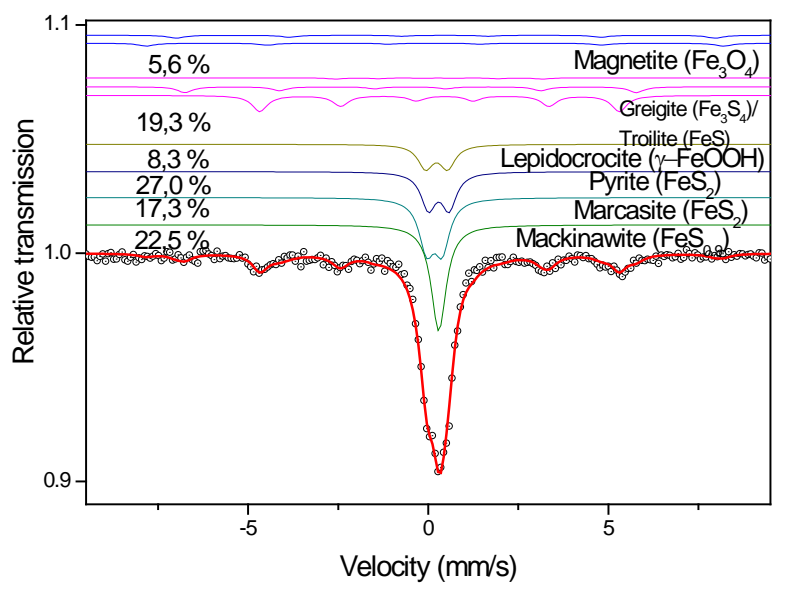

Figure 3. Compounds associated with iron obtained in Test 1.

The surface morphological analysis was performed by both scanning electron microscopy and elemental chemical analysis by Energy-dispersive X-ray spectroscopy (EDS) (Figure 4). The coupons showed uniform corrosion and numerous points with localized corrosion. Damage displaying important amplitude and depth is observed.

The EDS analysis in Figure 4(e) indicates the presence of oxygen, silicon, chlorine, manganese and iron. The most intense peaks correspond to iron and oxygen, whereas those with lower magnitude are associated with chlorine, silicon and manganese. These elements are considered as alloying metals, with exception of chlorine, which appears as a contaminant coming from brine. Figure 4(f) shows the EDS analysis performed on the dark spots observed on the surface; here, the presence of oxygen, sulfur and iron (residues of corrosion products, which were not completely removed during the blank cleansing) are observed, which indicates that the corrosion products formed on the steel surface are mainly iron sulfides with different stoichiometric ratios.

In addition, it is important to emphasize that a higher magnification of the surface allowed the visualization of cracks with different sizes, orientations and depths (Figure 5). This condition is considered as highly risky for the metal integrity once exposed to the high pressure and temperature conditions. This also would imply an accelerated corrosion process, exposing the steel to riskier situations [21].

On the other hand, the surface analysis for the steel exposed to the Test 2 conditions (with corrosion inhibitor presence) only showed uniform corrosion (Figure 6(a)) and some more damaged zones (Figure 6(b)). The elements detected by EDS analysis (Figure 6(c)) were iron, oxygen, antimony, silicon and manganese, which are considered as either part of the alloy or impurities of the very metal, except oxygen, which is assumed as part of some oxide present on the surface.

Higher magnified images allowed the observation of both a high density of pitting-type localized corrosion, distributed heterogeneously over the analyzed area and areas affected by corrosion localized on the scratch edges (Figure 7(a) and Figure $7(b)$ ). Figure 7 (c) shows the EDS analysis performed on the metal surface, where a typical composition of the used steel type is observed. 


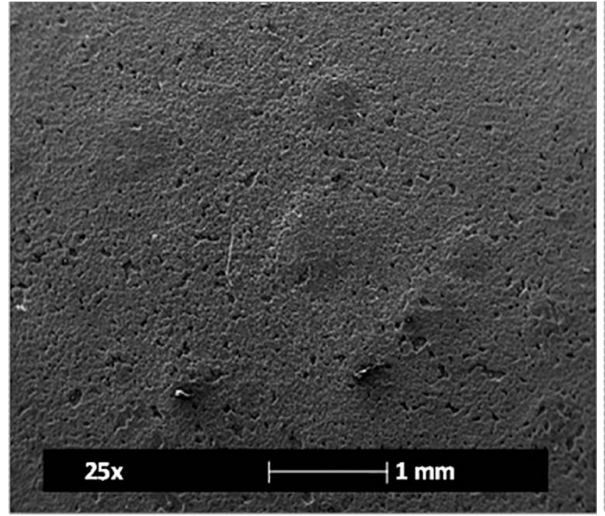

(a)

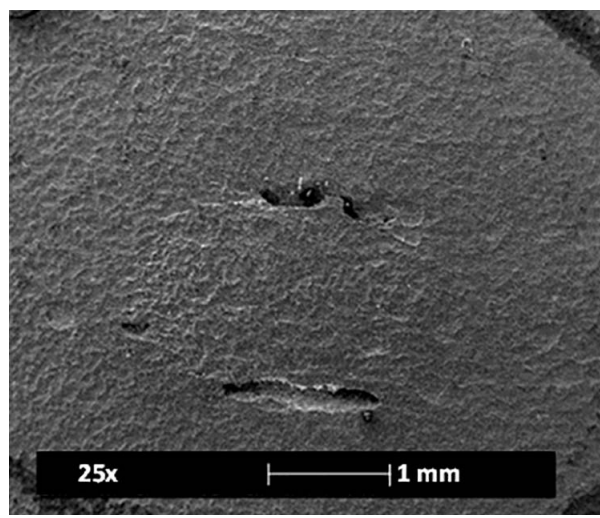

(c)

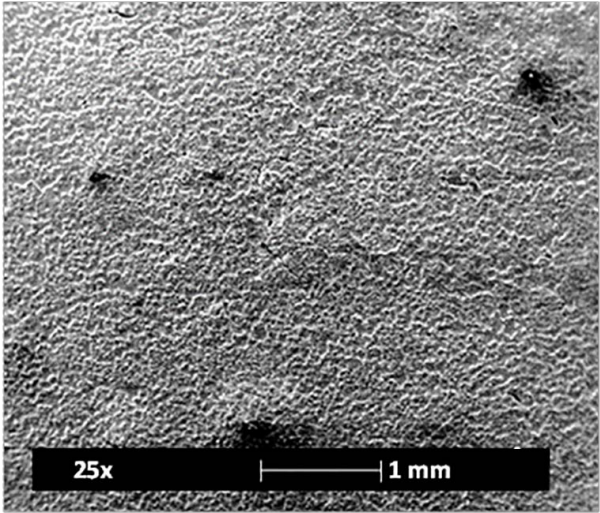

(b)

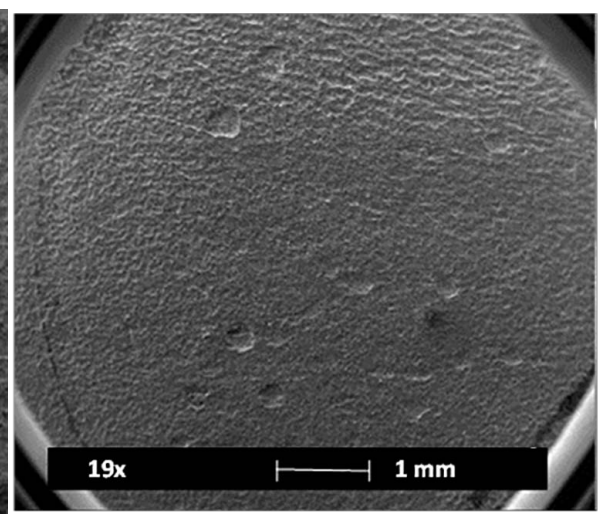

(d)

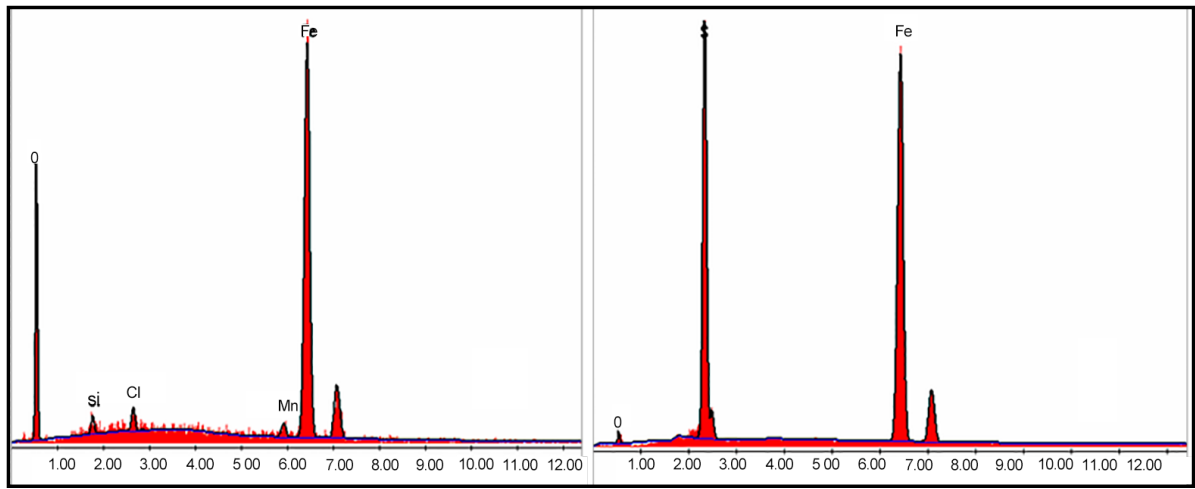

(e)

(f)

Figure 4. Surface analysis of API 5L X52 steel exposed to the conditions described for Test 1: (a) and (b) The surface shows elevations, dark spots (corrosion products) and different localized corrosion points, (c) and (d) uniform corrosion and presence of severe localized corrosion, elongated with considerable depth, (e) surface EDS analysis and (f) EDS analysis on dark spots.

Tests 3 and 4.

Tests 3 and 4 were carried out at a higher temperature $\left(115^{\circ} \mathrm{C}\right)$. The $\mathrm{pH}$ of the employed solution was 2.8 .

The corrosion rate in Test 3 (without corrosion inhibitor) was higher than the one 

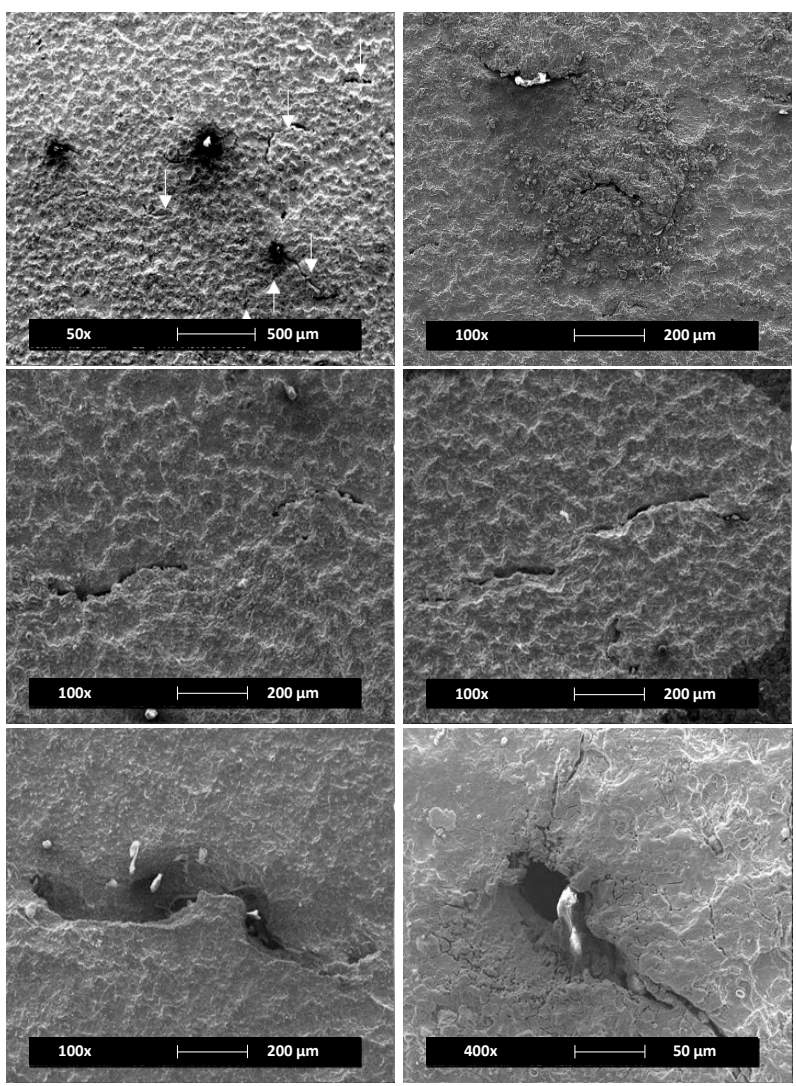

Figure 5. Presence of cracks on API 5L X52 steel exposed to the conditions described for Test 1 . This image series shows the occurrence of uniform corrosion. It is important to emphasize the presence of numerous cracks damages with different magnitudes and shapes.

obtained in Test 4 (Table 5). The average efficiency of the corrosion inhibitor under the test conditions was $84.87 \%$. It is important to mention that the corrosion inhibitor efficiency diminished about 10\% with respect to the efficiency obtained in Tests 1 and 2 , attributing such diminution to the temperature increase.

For Test 3, corrosion residues suspended in brine were observed, which were filtered to be analyzed. According to the results obtained by Mössbauer Spectroscopy (Figure 8), the presence of mackinawite and marcasite is observed, although pyrrhotite prevails evidently. Likewise, iron carbide or cementite is identified with a considerable percentage of $18.6 \%$. This compound was not identified in Test 1 .

Cementite is part of steel microstructure and occurs as a hard and fragile compound with a hardness value above 68 HRC. Its presence identified during the analyses is due to the flaking of some metal fractions as a consequence of the wearing out process occurring at the grain limits.

Figure 9 shows surface analysis images. Figure 9(a) features different magnitude elevations, some of them with dark spots, which are assumed as iron sulfides, taking into account the corresponding EDS analysis. 


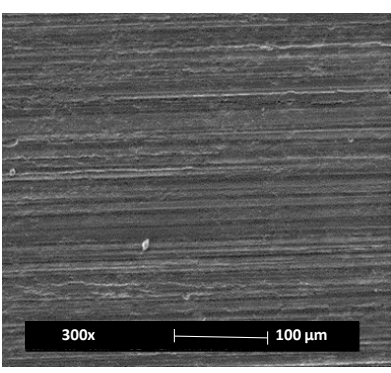

(a)

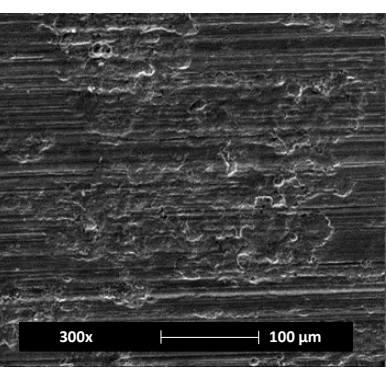

(b)

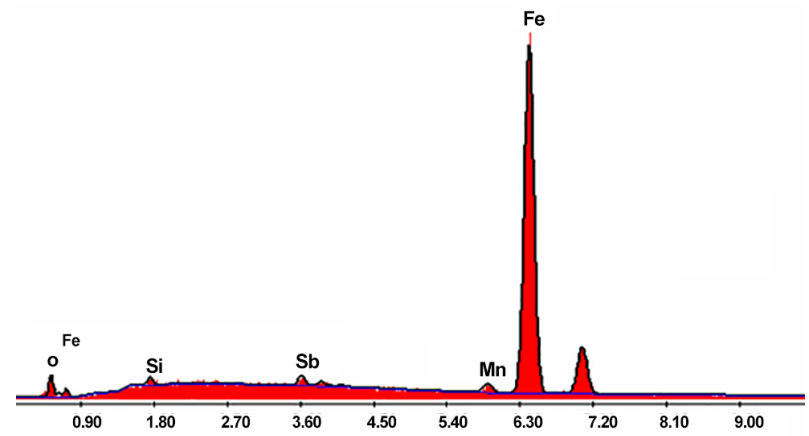

(c)

Figure 6. Surface analysis of API 5L X52 steel exposed to the conditions described for Test 2: (a) Uniform corrosion present in most of the analyzed areas, (b) highly damaged zones by generalized corrosion and (c) EDS analysis.

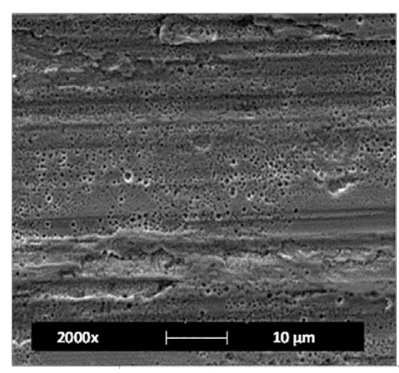

(a)

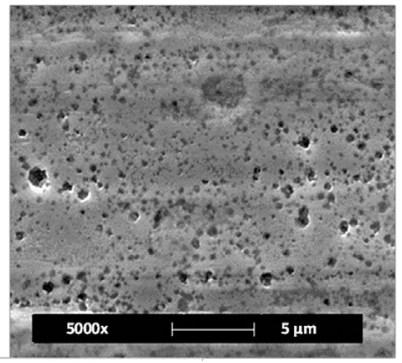

(b)

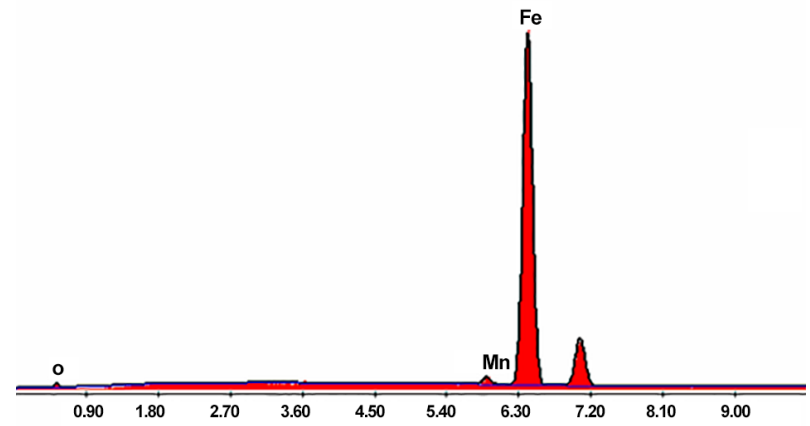

(c)

Figure 7. Test 2 surface analysis: (a) and (b) Presence of pittingtype damages, (c) EDS analysis. 
Table 5. Corrosion rates at $115^{\circ} \mathrm{C}$, hydrogen sulfide/carbon dioxide saturation, $70 \mathrm{~kg} \cdot \mathrm{cm}^{-2}$ and flow rate of $600 \mathrm{RPM}$.

\begin{tabular}{cccc}
\hline \multicolumn{2}{c}{ Test 3 blank without inhibitor } & \multicolumn{2}{c}{ Test $450 \mathrm{mg} \cdot \mathrm{L}^{-1}$ of corrosion inhibitor } \\
\hline $\begin{array}{c}\text { Average value of the } 8 \\
\text { used blanks }\end{array}$ & $\begin{array}{c}1.799 \mathrm{~mm} \cdot \mathrm{year}^{-1} \\
(70.84 \mathrm{mpy})\end{array}$ & $\begin{array}{c}\text { Average value of the } 8 \\
\text { used blanks }\end{array}$ & $\begin{array}{c}0.272 \mathrm{~mm} \cdot \mathrm{year}^{-1} \\
(9.022 \mathrm{mpy})\end{array}$ \\
\hline
\end{tabular}

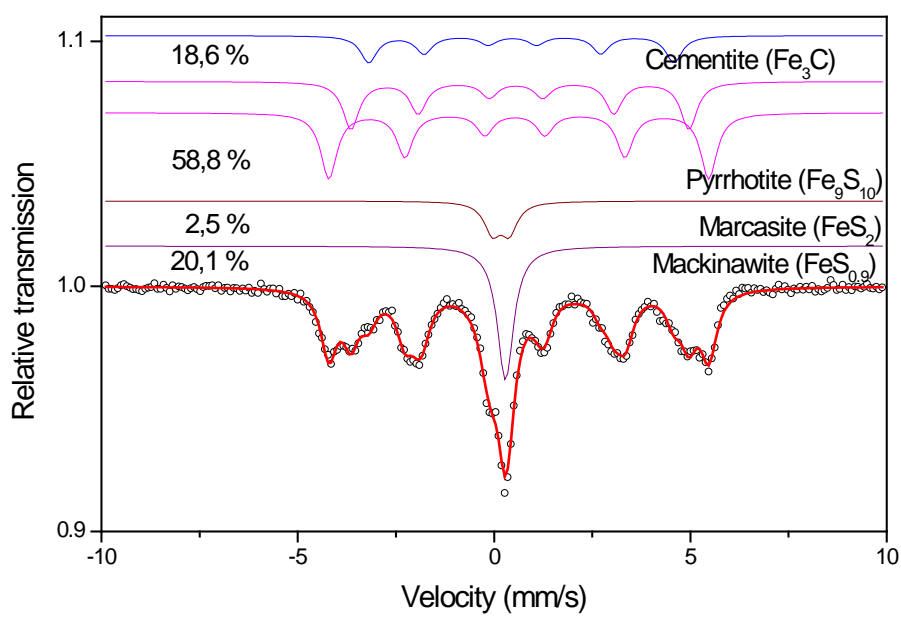

Figure 8. Compounds associated with iron obtained in Test 3.

Likewise, most of the surface shows tracks of vanished scratches due to the occurrence of a uniform corrosion process. By means of highly magnified images, the presence of cracks with different shapes and variable orientations is evidenced, as it can be observed in Figures 9(a)-(f). Different EDS analyses were carried out on the cracks, identifying oxygen, carbon, iron, silicon and aluminum.

For Test 4, which was carried out in the presence of corrosion inhibitor, the formation of corrosion products was not enough to perform their analysis. Figure 10 shows metal surface images, where slight uniform corrosion with isolated pitting is observed.

Tests 5 and 6.

These tests were carried out at $115^{\circ} \mathrm{C}$, but the difference with respect to the first four tests was that environment oxygen was not displaced, in order to have an additional corrosive agent (Table 6). The $\mathrm{pH}$ of the used solution was 2.88 .

The average corrosion rate of the corrosion blanks featured in Test 5 was higher than the one obtained in Test 6 . The efficiency of the corrosion inhibitor was lower than those observed in the previous tests, with an average value of $76.61 \%$.

Here, from the corrosion rate perspective, the combination of temperature and oxygen presence exerted a higher effect on the inhibitor performance.

The sediments recovered from Test 5, according to the Mössbauer Spectroscopy (Figure 11), indicate the presence of sulfides and iron oxides as corrosion products. Likewise, once again, the presence of cementite was identified, which is a compound that was found in the residues of Test 3 . However, with Test 5 , a lower content in the order of $2.5 \%$ was detected, which is in contrast with $18.6 \%$ reported in Test 3 . 


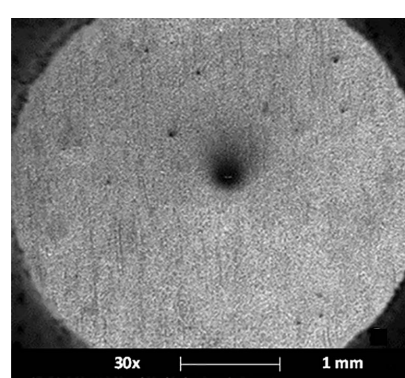

(a)

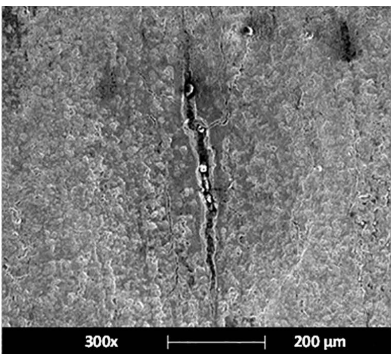

(c)

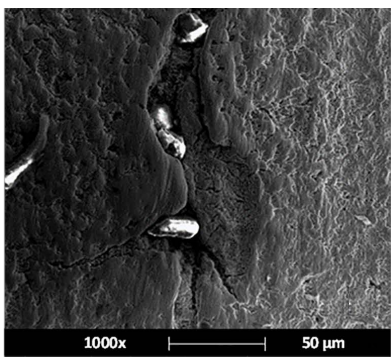

(e)

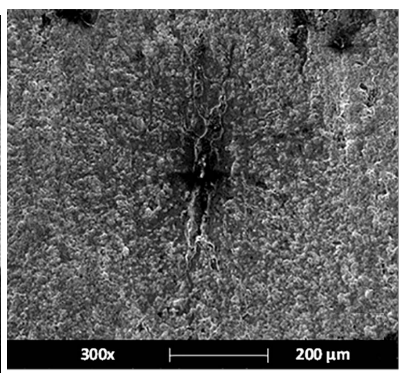

(b)

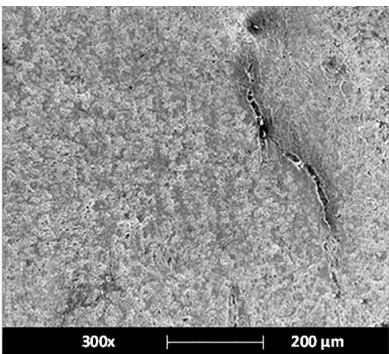

(d)

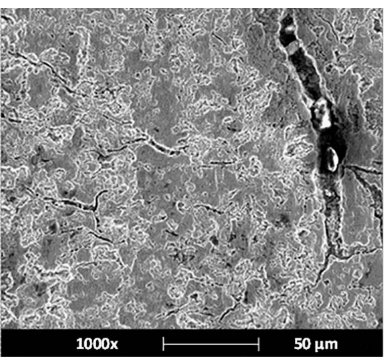

(f)

Figure 9. Presence of cracks on API 5L X52 steel exposed to the conditions described for Test 3: (a) Presence of uniform corrosion with localized corrosion zones, (b)-(f) damages caused by cracks with different magnitudes and shapes.
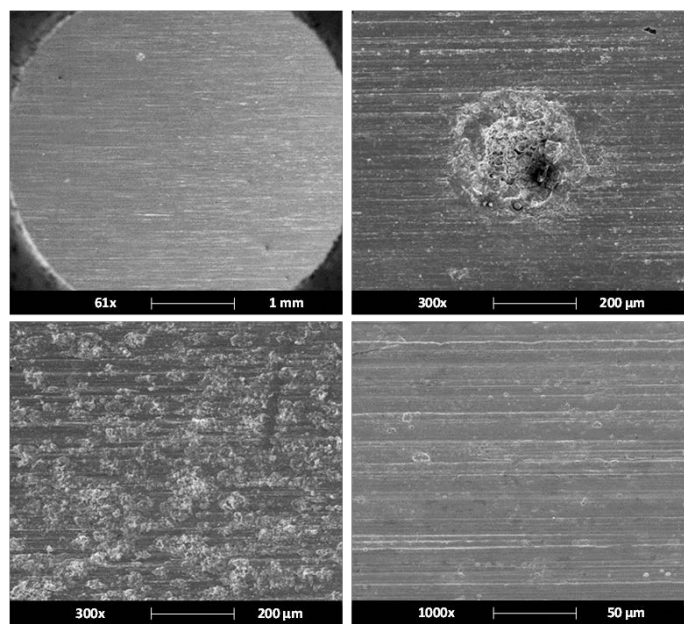

Figure 10. Surface analysis performed on API 5L X52 steel exposed to Test 4 condition. 
Table 6. Corrosion rates at $115^{\circ} \mathrm{C}$, hydrogen sulfide/carbon dioxide/oxygen saturation, $70 \mathrm{~kg}$. $\mathrm{cm}^{-2}$ and flow rate of $600 \mathrm{RPM}$.

\begin{tabular}{cccc}
\hline \multicolumn{2}{c}{ Test 5 blank without inhibitor } & \multicolumn{2}{c}{ Test $550 \mathrm{mg} \cdot \mathrm{L}^{-1}$ of corrosion inhibitor } \\
\hline $\begin{array}{c}\text { Average value of the } 8 \\
\text { used blanks }\end{array}$ & $\begin{array}{c}1.648 \mathrm{~mm} \cdot \mathrm{year}^{-1} \\
(64.904 \mathrm{mpy})\end{array}$ & $\begin{array}{c}\text { Average value of the } 8 \\
\text { used blanks }\end{array}$ & $\begin{array}{c}0.390 \mathrm{~mm} \cdot \mathrm{year}^{-1} \\
(15.178 \mathrm{mpy})\end{array}$ \\
\hline
\end{tabular}

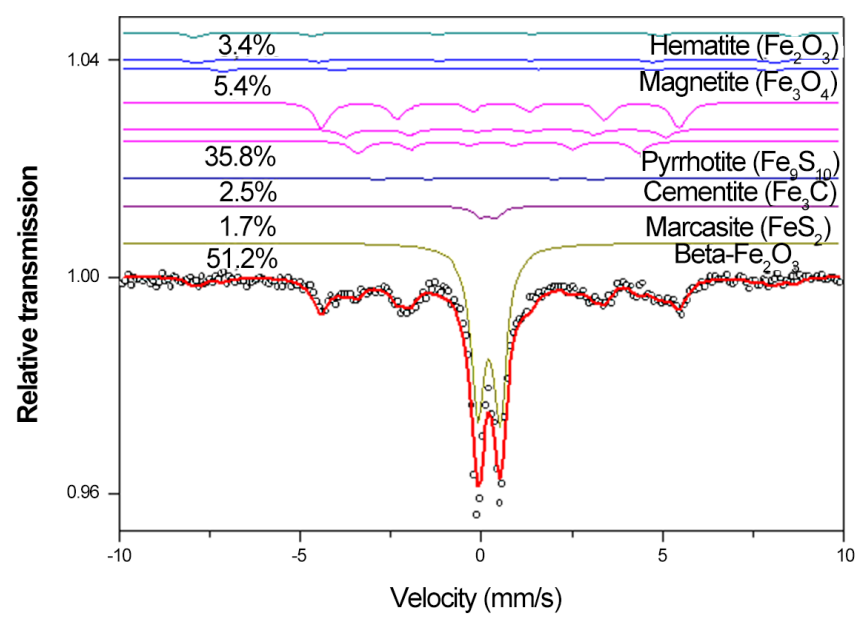

Figure 11. Compounds associated with iron obtained in Test 5.

The surface analysis for steel exposed to Test 5 conditions is shown in Figure 12 . Here, uniform corrosion all over the blank surface with some localized corrosion spots is shown. With higher magnification (Figure 12(c) and Figure 12(d)), some preferential cracking on the base material is observed, identifying the presence of metal fractures.

The cracking occurring in Test 5 is apparently of lesser magnitude in comparison with the one observed in Test 3 . The extent and depth displayed by the Test 3 cracks allow the deposit of particles inside them, which is not observed in the images of Test 5 cracks.

The surface analysis of the steel exposed to Test 6 conditions (with inhibitor presence) only shows slight uniform corrosion (Figure 13) with white spots on some areas that correspond to some material lobes formed on the surface.

\section{Discussion}

The corrosion rate of the evaluated blanks in corrosion inhibitor absence decreased as the temperature was increased from 70 to $115^{\circ} \mathrm{C}$ and it falls lower when oxygen is not displaced from the system, as shown in Figure 14. This fact could indicate that the corrosion products formed on the metal surface are more protective at higher temperatures with oxygen presence.

However, it is worth emphasizing the presence of damage on the steel surface through localized processes such as pitting, fractures or cracking. The aforesaid could limit the meaning and interpretation given to the corrosion rate parameter, as they only consider uniform corrosion. 


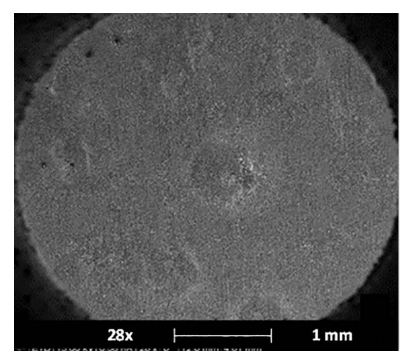

(a)

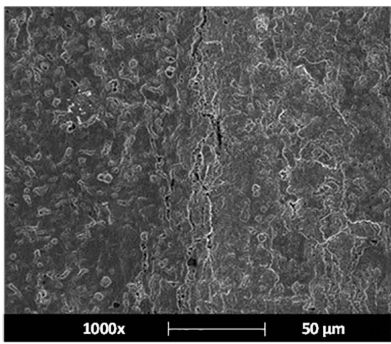

(c)

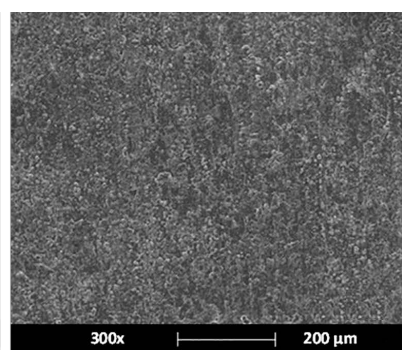

(b)

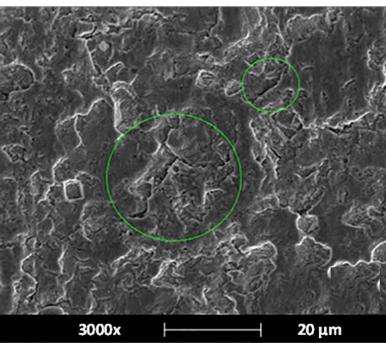

(d)

Figure 12. Surface analysis of API 5L X52 steel exposed to Test 5 conditions: (a) and (b) Uniform corrosion surface, (c) and (d) presence of surface cracks.
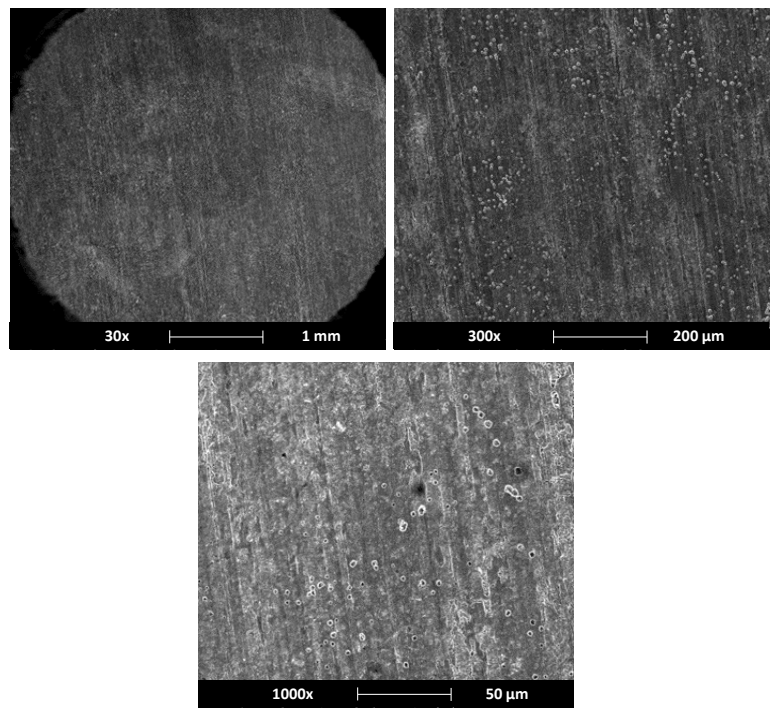

Figure 13. Surface analysis of API 5L X52 steel exposed to Test 6 conditions.

In environments with hydrogen sulfide/carbon dioxide saturation, the presence of iron sulfides and carbonates would be expected. Nevertheless, as already shown by different studies [22] [23] [24] [25] [26], the formation of carbonates is not significant under the tested conditions and the formation kinetics of sulfides prevails during the process. Thus, the analysis of the corrosion products formed during the performed tests with hydrogen sulfide/carbon dioxide saturation shows that iron sulfides prevail at both test temperatures, with values above 80 weight $\%$. 


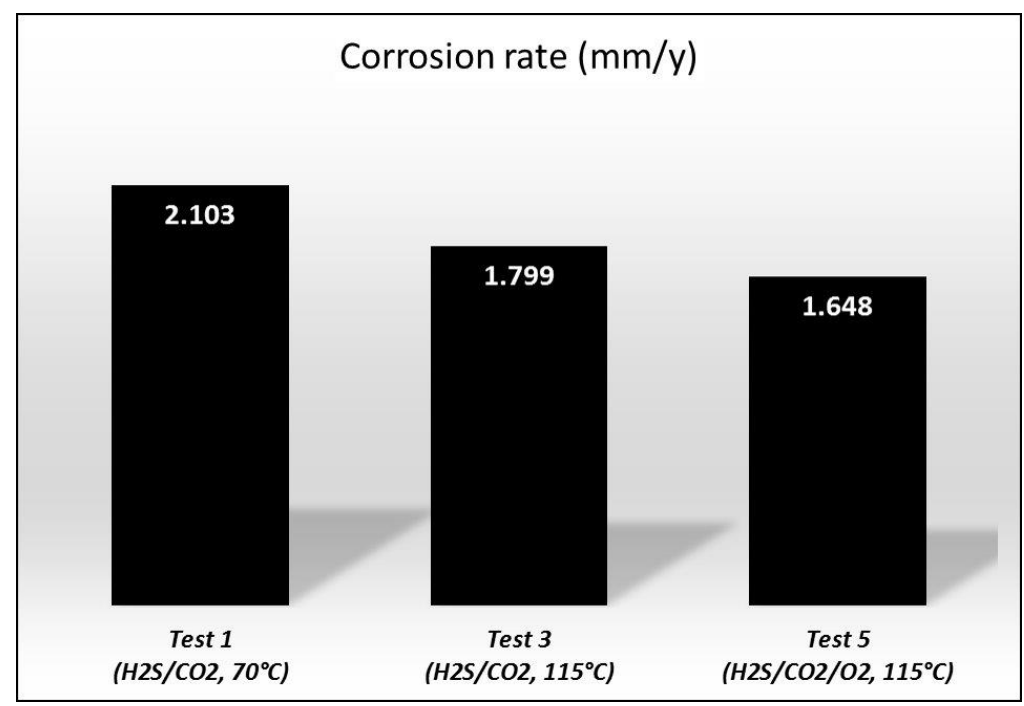

Figure 14. Corrosion rates in tests considered as blanks, using $10 \% \mathrm{NaCl}$ brine, $70 \mathrm{~kg} \cdot \mathrm{cm}^{-2}$, rotation rate of $600 \mathrm{RPM}$ and API 5L X52 steel exposure time of $24 \mathrm{~h}$.

However, there are differences among the sulfide species formed at each temperature; although the presence and proportion of mackinawite is constant in both tests with a value around $20 \%$. As it has already been shown by other researchers, this compound is formed extremely quickly and it is considered as the first sulfide formed in hydrogen sulfide environments [27] [28] [29] [30].

In this way, at $70^{\circ} \mathrm{C}$ the presence of sulfides and some oxides that are commonly observed in the sediments present in pipelines transporting sour hydrocarbons occurs; whereas at $115^{\circ} \mathrm{C}$, only three sulfide species are identified, where pyrrhotite prevails remarkably with around $60 \%$.

In addition, it is worth mentioning the presence of cementite or silicon carbide $(18 \%)$ in the obtained products during the tests performed at $115^{\circ} \mathrm{C}$. This compound is not a corrosion product for it corresponds to the material that is part of the steel microstructure [31] and its presence is attributed to a phase flake resulting from the occurring corrosion process.

On the other hand, when oxygen is not displaced from the system, the presence of oxides is favored, which affects the formation of sulfides. According to Test 5 results, the hematite and magnetite oxides represented around $60 \%$ of the obtained products, whereas $40 \%$ was constituted by iron sulfides, being pyrrhotite the prevailing sulfide. In addition, under these conditions, the presence of cementite is also observed, although with a lower proportion of $2.5 \%$.

The results of the performed tests show how the corrosion products formed on the surface of the blanks are made up of different species depending on the test conditions. This fact has to be reflected on the surface protection condition.

The corrosion type observed in Tests 1 and 3 seems, at first sight, generalized; however, there are localized corrosion spots. Likewise, the presence of cracks on the metal 
surface becomes of more interest for the surface analysis. These fractures can be the beginning of more serious damage for the integrity of API 5L X52 steel, when exposed to environments with high hydrogen sulfide contents. Under these conditions, the development of some characteristic corrosion processes such as hydrogen induced cracking (HIC), sulfide stress cracking (SSC) and stress-oriented-hydrogen-induced cracking (SOHIC) [32] [33] [34] has been observed. In this particular case and according to what has been established by some researchers, this corrosion type would seem to be the most common failure for the steel, being the most dangerous mechanism for a metal fracture, as it can occur instantaneously without previous warning [21].

According to the aforesaid, it is necessary that a suitable corrosion control system be implemented in the field when intending to handle fluids with high hydrogen sulfide and carbon dioxide concentrations through transport pipelines made of API 5L X52 steel. The previous statement stems from the fact that this material seems no to be the most suitable one for this type of fluids.

\section{Corrosion Inhibitor Efficiency}

The performance of the corrosion inhibitor currently used in the transport and distribution pipelines of the Gulf of Mexico region was evaluated. Such corrosion inhibitor is a commercial product based on modified imidazolines which works as a film-forming inhibitor.

The corrosion rates of the coupons exposed to the same conditions used for the three corresponding blanks, but with a chemical additive concentration of $50 \mathrm{mg} \cdot \mathrm{L}^{-1}$, are shown in Figure 15. These data correspond to Tests 2, 4 and 6.

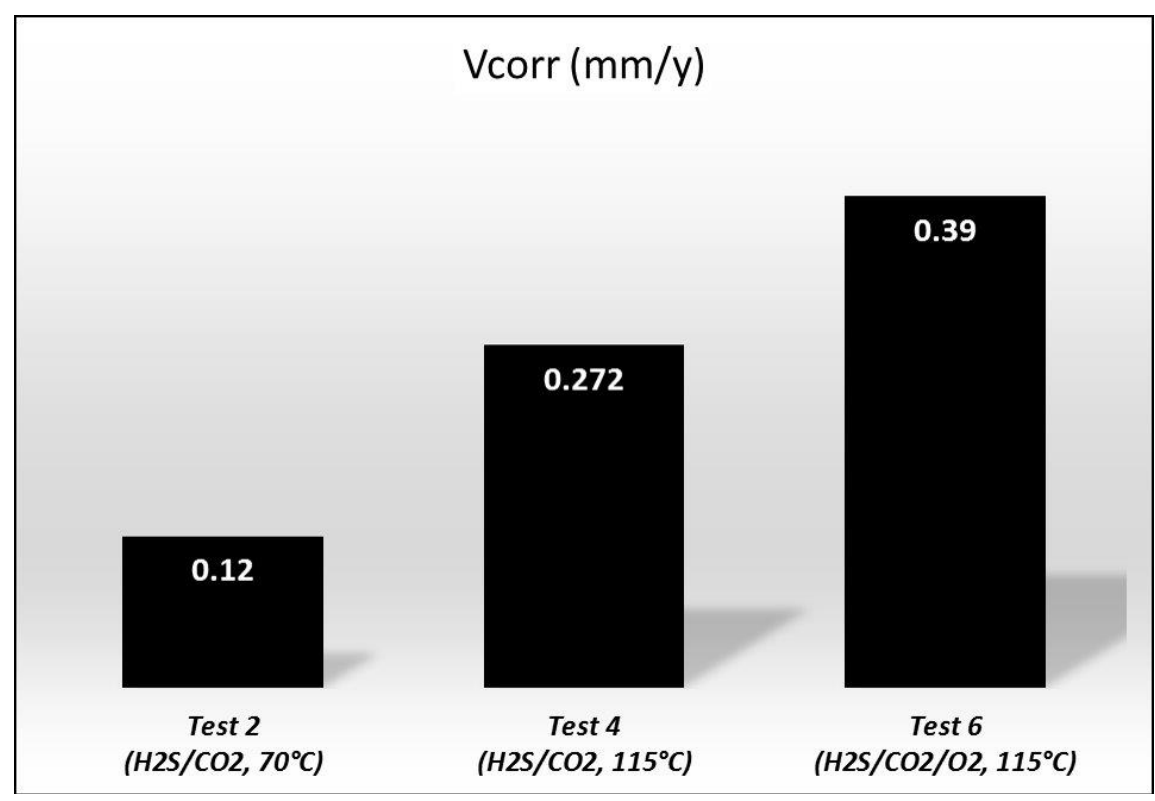

Figure 15. Corrosion rates for corrosion inhibitor tests using $10 \% \mathrm{NaCl}$ brine, $70 \mathrm{~kg}$. $\mathrm{cm}^{-2}$, rotation rate of $600 \mathrm{RPM}$, API 5L X52 steel exposure time of $24 \mathrm{~h}$ and corrosion inhibitor concentration of $50 \mathrm{mg} \cdot \mathrm{L}^{-1}$. 
It is evident that the corrosion rates are too low in comparison with those obtained for the blanks. Here, with corrosion inhibitor presence, a behavior that is opposite to the one displayed by the blanks is observed, which has already been reported for inhibitors of the same type [35]. The corrosion rate is lower at $70^{\circ} \mathrm{C}$, which was increased at $115^{\circ} \mathrm{C}$ and became higher when oxygen was not displaced.

With the obtained corrosion rates in each pair of tests, the inhibitor efficiency was calculated according to the following equation:

$$
\text { efficiency }(\%)=\frac{\text { blank weight loss }- \text { inhibited weight }}{\text { blank weight loss }} \times 100
$$

At $70^{\circ} \mathrm{C}$ and with hydrogen sulfide/carbon dioxide presence, the corrosion inhibitor seems to provide good metal protection, obtaining an efficiency of $94 \%$, whereas by increasing the temperature to $115^{\circ} \mathrm{C}$, the efficiency is decreased to $84 \%$. Likewise, the inhibitor exhibited poorer performance in the tests where oxygen was not displaced, with $76.3 \%$ efficiency (Table 7 ).

Nevertheless, even when chemical product efficiency is observed, it is worth noting that the estimated data consider a uniform corrosion process all over the surface of the blanks. In this way, the analysis of the protection provided by the corrosion inhibitor becomes relevant.

In the case of the first test set, the obtained efficiency rate is acceptable; however, the surface analysis of the blanks in the presence of corrosion inhibitor evidenced a high pitting density. This fact implies that the corrosion inhibitor is not protecting enough under the tested conditions. Likewise, it is evident that the corrosion process is very different in absence and presence of chemical additive for when it was added neither fractures nor cracks were observed.

For the second test set, the corrosion inhibitor efficiency was diminished, but no cracks or any other localized corrosion phenomenon were observed. Likewise, for the third test set, the corrosion inhibitor efficiency displayed the lowest value, but with better inhibition of cracks and localized corrosion.

In this way, it is worth mentioning that the average field dosage of corrosion inhibitor used in the transport pipelines located in the Gulf of Mexico zone is in the order of 10 to $20 \mathrm{ppm}$. Likewise, the local normativity applicable in the matter of pipeline internal corrosion control [36] establishes that the efficiency of chemical products has to be evaluated at concentrations ranging from 5 to $50 \mathrm{ppm}$. The minimal efficiency looked for a chemical product to be used in the field is $90 \%$, obtained by means of a gravimetric technique and without showing any kind of pitting.

According to the previously mentioned, the employed corrosion inhibitor would not

Table 7. Corrosion inhibitor efficiency.

\begin{tabular}{ccc}
\hline \multicolumn{3}{c}{$50 \mathrm{mg} \cdot \mathrm{L}^{-1}$ of corrosion inhibitor } \\
\hline $70^{\circ} \mathrm{C}-\mathrm{H}_{2} \mathrm{~S} / \mathrm{CO}_{2}$ & $115^{\circ} \mathrm{C}-\mathrm{H}_{2} \mathrm{~S} / \mathrm{CO}_{2}$ & $115^{\circ} \mathrm{C}-\mathrm{H}_{2} \mathrm{~S} / \mathrm{CO}_{2} / \mathrm{O}_{2}$ \\
$94.3 \%$ & $84.9 \%$ & $76.3 \%$ \\
\hline
\end{tabular}


match the established requisites, even at the highest concentration recommended by the applicable normativity. At this point, it is worth noting that the film-forming corrosion inhibitors have shown in the laboratory efficiencies that are above $90 \%$ with concentrations below $25 \mathrm{ppm}$, according to the applicable normativity. This performance seems to work well under the average conditions that prevail in the hydrocarbon transport pipelines in the Gulf of Mexico region, which take into account hydrogen sulfide and carbon dioxide contents ranging from 2 to $4 \%$, establishing corrosion rates below $0.05 \mathrm{~mm} \cdot \mathrm{year}^{-1}$ ( $2 \mathrm{mpy}$ ) in most of the evaluated pipelines.

Notwithstanding, the possible effects exerted on the performance of the corrosion inhibitors for the transport of fluids with higher hydrogen sulfide and carbon dioxide contents, makes compulsory the performance of more detailed studies aimed at establishing new criteria in the evaluation of products in the laboratory. This is in order to make a selection for inhibitor field application and to provide safer conditions in handling hydrocarbons with high acid gas contents.

\section{Conclusions}

According to the obtained results and considering the test conditions featured in the present work, the hydrogen sulfide content exerts a higher impact on the corrosion processes occurring at the API 5L X52 steel coupons, as the mainly observed corrosion products are sulfides and no carbonate presence is detected. Likewise, when oxygen is not displaced from the system, the formation of iron oxides is favored, which appears with a proportion that is close to $60 \%$, competing with the formation of sulfides.

This sulfide and oxide proportion seems to exert an effect on both the wearing out rate and the corrosion type occurring on the steel surface. The corrosion rate is inversely proportional to the system temperature and the oxygen presence becomes a variable that increases this effect.

Likewise, it is worth noting that the displayed corrosion type also seems to be different depending on the test conditions. With corrosion inhibitor absence and oxygen displacement, an important effect of hydrogen sulfide on the surface metal occurs, where the prevailing corrosion type is SSC. At this point, the observed cracks show a considerable extent and they could even have provoked metal flaking, which is shown by the presence of cementite observed in the tests performed at $115^{\circ} \mathrm{C}$. The development of this type of corrosion damage constitutes a high-risk condition for the integrity of the materials submitted to pressure and temperature conditions.

On the other hand, when oxygen is not displaced, the corrosion type produced by the hydrogen sulfide content is less evident and a uniform corrosion effect on the metal surface is also observed, which prompts the formation of oxides due to oxygen influence. In this way, even when SSC damage still appears, the observed cracks have less extent and depth and the uniform corrosion on the surface of the blanks becomes more evident.

The corrosion inhibitor used in the experiment showed high efficiency at a concentration of $50 \mathrm{ppm}$ when evaluated in presence of hydrogen sulfide/carbon dioxide and 
at $70^{\circ} \mathrm{C}$. Likewise, although no fractures damage was observed, the blanks suffered severe pitting corrosion. For this reason, the obtained efficiency value has to be dealt with the correspondent considerations and stop being regarded as a corrosion inhibitor performance criterion. It is considered that at this temperature, the corrosion inhibitor does not exhibit the expected behavior.

On the other hand, the corrosion rates of the coupons obtained in the tests carried out at $115^{\circ} \mathrm{C}$, with and without air displacement, displayed good corrosion inhibition efficiency values of $84 \%$ and $76 \%$, respectively. Likewise, the surface analysis indicated a suitable control of the SSC-type corrosion processes, only observing generalized corrosion.

After taking into account the performance featured by the corrosion inhibitor, it is necessary that the optimal application conditions be identified, considering both different concentrations and the possible combination with other chemical products [35] [37].

Likewise, it is necessary to establish the magnitudes of the hydrogen sulfide/carbon dioxide concentration changes, due to the incorporation of currents coming from new wells, to the current transport and distribution systems. In addition, operation condition changes that will be needed to ensure the safe handling and flow of these hydrocarbons will have to be considered. This will give more precise parameters in the evaluation of corrosion inhibitors' performance, which is required for protection of pipeline systems.

It is important to point out that the hydrocarbons transport and distribution network from the Gulf of Mexico comprise more than three hundred pipelines, handling hydrocarbons with $\mathrm{H}_{2} \mathrm{~S}$ and $\mathrm{CO}_{2}$ contents between $2 \%$ and $4 \%$. These fluids are handled under acceptable security conditions throughout the pipelines already installed, as long as a corrosion inhibitor dosage is considered. However, because a gradual increment on the concentrations of $\mathrm{H}_{2} \mathrm{~S}, \mathrm{CO}_{2}$ and $\mathrm{H}_{2} \mathrm{O}$ is expected, a huge impact on the pipelines integrity is estimated.

This situation is not considered as a materials' selection problem as a replacement of the pipelines is no feasible. Thereby, it becomes necessary to keep a continuous tracking of the steel corrosion rates and pay special attention to the type of corrosion that develops at the metal surface. This is because different damage from the uniform corrosion observed until now may appear.

According with the last, it is recommendable to consider the use and/or development of other corrosion inhibitors, specifically designed for handling fluids with high $\mathrm{H}_{2} \mathrm{~S}$, $\mathrm{CO}_{2}$ and water concentrations.

\section{References}

[1] Duan, Y., Yu, F., Zhao, D., Cui, X. and Cui, Z. (2013) The Inhibition Performance of a New Imidazoline Derivative for Mild Steel in an Oil and Gas Field. Petroleum Science and Technology, 31, 1959-1966. http://dx.doi.org/10.1080/10916466.2011.553653

[2] Gregg, M.R. and Ramachandran, S. (1999) Review of Corrosion Inhibitor Developments and Testing for Offshore Oil and Gas Production Systems. Corrosion Conference and Expo 
(CORROSION2004), New Orleans, 28 March-1 April 2004, Paper 04422.

[3] Jovancicevic, V., Ramachandran, S. and Prince, P. (1999) Inhibition of Carbon Dioxide Corrosion of Mild Steel by Imidazolines and Their Precursors. Corrosion, 55, 449-455. http://dx.doi.org/10.5006/1.3284006

[4] Svenningsen, G., Palencsár, A. and Kvarekvål, J. (2009) Investigation of Iron Sulfide Surface Layer Growth in Aqueous $\mathrm{H}_{2} \mathrm{~S} / \mathrm{CO}_{2}$ Environments. Corrosion Conference and Expo (CORROSION 2009): A Hit in the Heart of the South, Atlanta, 22-26 March 2009, Paper 09359.

[5] Maa, H., Cheng, X., Li, G., Chen, S., Quan, Z., Zhao, S. and Niu, L. (2000) The Influence of Hydrogen Sulfide on Corrosion of Iron under Different Conditions. Corrosion Science, 42, 1669-1683. http://dx.doi.org/10.1016/S0010-938X(00)00003-2

[6] Liu, M., Wang, J. and Ke, W. (2013) Corrosion Behavior of X52 Pipeline Steel in High $\mathrm{H}_{2} \mathrm{~S}$ Concentration Solutions at Temperatures Ranging from $25^{\circ} \mathrm{C}$ to $140^{\circ} \mathrm{C}$. Corrosion Engineering, Science and Technology, 48, 380-387. http://dx.doi.org/10.1179/1743278213Y.0000000095

[7] Zhou, C., Chen, X., Wang, Z., Zheng, S., Li, X. and Zhang, L. (2014) Effects of Environmental Conditions on Hydrogen Permeation of X52 Pipeline Steel Exposed to High $\mathrm{H}_{2} \mathrm{~S}$-Containing Solutions. Corrosion Science, 89, 30-37. http://dx.doi.org/10.1016/j.corsci.2014.07.061

[8] Gencheva, G., Coxa, K., Trana, H., Sarfraza, A., Bosch, C., Spiegel, M. and Erbe, A. (2015) Metallic, Oxygen-Containing Reaction Products after Polarization of Iron in $\mathrm{H}_{2} \mathrm{~S}$ Saturated Saline Solutions. Corrosion Science, 98, 725-736.

http://dx.doi.org/10.1016/j.corsci.2015.06.017

[9] Shi, F., Zhang, L., Yang, J., Lu, M., Ding, J. and Lia, H. (2016) Polymorphous FeS Corrosion Products of Pipeline Steel under Highly Sour Conditions. Corrosion Science, 102, 103-113. http://dx.doi.org/10.1016/j.corsci.2015.09.024

[10] Tang, J., Shao, Y., Guo, J., Zhang, T., Meng, G. and Wang, F. (2010) The Effect of $\mathrm{H}_{2} \mathrm{~S}$ Concentration on the Corrosion Behavior of Carbon Steel at $90^{\circ}$ C. Corrosion Science, 52, 2050 2058. http://dx.doi.org/10.1016/j.corsci.2010.02.004

[11] Zhang, G.A., Zeng, Y., Guo, X.P., Jiang, F., Shi, D.Y. and Chen, Z.Y. (2012) Electrochemical Corrosion Behavior of Carbon Steel under Dynamic High Pressure $\mathrm{H}_{2} \mathrm{~S} / \mathrm{CO}_{2}$ Environment. Corrosion Science, 65, 37-47. http://dx.doi.org/10.1016/j.corsci.2012.08.007

[12] Ningn, J., Zheng, Y., Brown, B., Young, D. and Nesic, S. (2015) Construction and Verification of Pourbaix Diagrams for Hydrogen Sulfide Corrosion of Mild Steel. NACE International, Corrosion 2015 Conference and Expo, Paper No. 5507.

[13] NACE 1D 182. Wheel Test Method Used for Evaluation of Film-Persistent Corrosion Inhibitors for Oilfield Applications.

[14] ASTM G184-06 (2012) Standard Practice for Evaluating and Qualifying Oil Field and Refinery Corrosion Inhibitors Using Rotating Cage.

[15] ASTM G46-94 (2013) Standard Guide for Examination and Evaluation of Pitting Corrosion.

[16] ASTMG1-03 (2011) Standard Practice for Preparing, Cleaning, and Evaluating Corrosion Test Specimens.

[17] NACE RP-775 (2005) Standard Recommended Practice Preparation, Installation, Analysis, and Interpretation of Corrosion Coupons in Oilfield Operations.

[18] ASTM D1141-98 (2013) Standard Practice for the Preparation of Substitute Ocean Water. 
[19] ASTM E70-07 (2015) Standard Test Method for pH of Aqueous Solutions with the Glass Electrode.

[20] Brand, R.A. (1987) Normos Mössbauer Fitting Program. The NORMOS Program Is Available from Wissel GmbH, Starnberg.

[21] Cheng, Y. (2013) Stress Corrosion Cracking of Pipelines. Wiley, Hoboken. http://dx.doi.org/10.1002/9781118537022

[22] Nesic, S., Zheng, Y., Brown, B. and Ning, J. (2016) Advancement in Predictive Modeling of Mild Steel Corrosion in $\mathrm{CO}_{2}$ and $\mathrm{H}_{2} \mathrm{~S}$ Containing Environments. CORROSION, 72, 679691. http://dx.doi.org/10.5006/1667

[23] Shoesmith, D.W., Taylor, P., Bailey, M.G. and Owen, D.G. (1980) The Formation of Ferrous Monosulfide Polymorphs during the Corrosion of Iron by Aqueous Hydrogen Sulfide at $21^{\circ}$ C. Journal Electrochemical Society, 125, 1007-1015. http://dx.doi.org/10.1149/1.2129808

[24] Smith, S.N. (1993) A Proposed Mechanism for Corrosion in Slightly Sour Oil and Gas Production. 12 th International Corrosion Congress, Houston, 19-24 September 1993, Paper No. 385.

[25] Smith, S.N. and Wright, E.J. (1994) Prediction of Minimum $\mathrm{H}_{2} \mathrm{~S}$ Levels Required for Slightly Sour Corrosion. Corrosion Conference and Expo (CORROSION 1994), Houston, 1994, Paper 94.

[26] Sun, W. and Nešić, S. (2009) A Mechanistic Model of Uniform Hydrogen Sulfide/Carbon Dioxide Corrosion of Mild Steel. CORROSION, 65, 291-307. http://dx.doi.org/10.5006/1.3319134

[27] Sun, W. and Nesic, S. (2007) A Mechanistic Model of $\mathrm{H}_{2} \mathrm{~S}$ Corrosion of Mild Steel. Corrosion Conference and Expo (CORROSION 2007), Nashville, 11-15 March 2007, Paper 07655 .

[28] Rickard, D. and Luther, G.W. (1997) Kinetics of Pyrite Formation by the $\mathrm{H}_{2} \mathrm{~S}$ Oxidation of Iron (II) Monosulfide in Aqueous Solutions between 25 and $125^{\circ} \mathrm{C}$, the Mechanism. Geochimica et Cosmochimica Acta, 61, 135-147. http://dx.doi.org/10.1016/S0016-7037(96)00322-5

[29] Robert, B.A. (1967) Thermodynamic Stability of Sedimentary Iron Sulfides. American Journal of Science, 265, 773-785. http://dx.doi.org/10.2475/ajs.265.9.773

[30] Smith, S.N. and Pacheco, J.L. (2002) Prediction of Corrosion in Slightly Sour Environment. Corrosion Conference and Expo (CORROSION 2002), Denver, 7-11 April 2002, Paper 02241.

[31] Zheng, Y., Ning, J., Brown, B., Young, D. and Nesic, S. (2015) Mechanistic Study of the Effect of Iron Sulfide Layers on Hydrogen Sulfide Corrosion of Carbon Steel. Corrosion Conference and Expo (CORROSION2015), Dallas, 15-19 March 2015, Paper 5933.

[32] Serna, S. and Albarrán, J.L. (2003) Effect of Wet Hydrogen Sulfide Environments on the Cracking Susceptibility of Medium Strength Microalloyed Pipeline Steels for Oil and Gas Transport. Corrosion Conference and Expo (CORROSION 2015), Dallas, 16-20 March 2015, Paper 03530.

[33] Mendibile, C. and Sourmail, T. (2009) Composition Optimization of High-Strength Steels for Sulfide Stress Cracking Resistance Improvement. Corrosion Science, 51, 2878-2884. http://dx.doi.org/10.1016/j.corsci.2009.08.013

[34] Kittel, J., Smanio, V., Fregonese, M., Garnier, L. and Lefebvre, X. (2010) Hydrogen Induced Cracking (HIC) Testing of Low Alloy Steel in Sour Environment: Impact of Time of Exposure on the Extent Of Damage. Corrosion Science, 52, 1386-1392. 
http://dx.doi.org/10.1016/j.corsci.2009.11.044

[35] Chen, H.J., Hong, T. and Paul Jepson, W. (2000) High Temperature Corrosion Inhibition Performance of Imidazoline and Amide. Corrosion Conference and Expo (CORROSION 2000), Orlando, March 2000, Paper 00035.

[36] NRF-005-PEMEX (2009) Protección interior de ductos con inhibidores.

[37] Zhao, J., Duan, H. and Jiang, R. (2015) Synergistic Corrosion Inhibition Effect of Quinoline Quaternary Ammonium Salt and Gemini Surfactant in $\mathrm{H}_{2} \mathrm{~S}$ and $\mathrm{CO}_{2}$ Saturated Brine Solution. Corrosion Science, 91, 108-119. http://dx.doi.org/10.1016/j.corsci.2014.11.007

Submit or recommend next manuscript to SCIRP and we will provide best service for you:

Accepting pre-submission inquiries through Email, Facebook, LinkedIn, Twitter, etc. A wide selection of journals (inclusive of 9 subjects, more than 200 journals)

Providing 24-hour high-quality service

User-friendly online submission system

Fair and swift peer-review system

Efficient typesetting and proofreading procedure

Display of the result of downloads and visits, as well as the number of cited articles

Maximum dissemination of your research work

Submit your manuscript at: http://papersubmission.scirp.org/

Or contact msa@scirp.org 